\title{
Improving Tangible Strategy for Botanical Gardens Expansion in Indonesia (Case Study in Bogor Botanical Gardens)
}

\author{
Muhammad Nashar \\ Agustinus Haryadi DP
}

\begin{abstract}
This study is to analysis the implementation on tangible strategy in Bogor Botanical Gardens towards processing to become World Heritage. The process has been doing related with Bogor Botanical Gardens vision to protect and increasing value of the Gardens. The Bogor Botanical Gardens which is the oldest Botanical Garden in Indonesia has been applying tangible strategy i.e. Management system, strategic planning, human resources planning and become center of excellence for international research. Based on the interview the effort to fight the Gardens as a Universal cultural Heritage are the first step to achieve a national identity and support the sustainable development of the World Heritage. The conservation efforts need to be understood and interpreted to have high benefits as a generator of economic growth, social, culture for the city of Bogor and society at large, in order to achieve a balance of environmental, security-safety and public health as well as thesustainability of the botanical gardens.
\end{abstract}

DOI: $10.7176 / \mathrm{JESD} / 11-2-08$

Publication date: January $31^{\text {st }} 2020$

\section{I.Introduction}

Bogor Botanical Gardens (BBGs) is one of the Indonesian Heritage is currently being sought to be recognized as a World Heritage which has survived for hundreds of years in an urban environment. Strategic function of BBGs require community attention in order to manifest a sustainable BBGs. (Hotimah, Wirutomo, \& Alikodra, 2015)

Tourism is one of the largest and fastest growing industries in the world today including in Indonesia. The tourism sector is an important source of increasing income, creating jobs and prosperity in many countries, the Government of Indonesia has set a target of 14\% of GDP in the tourism sector which has now reached less than $7 \%$. The Ministry of Tourism has set a target of tourist visits to Indonesia in 2016 of 272 million tourists. The amount is divided into 12 million foreign tourists and 260 million domestic tourists. "The target of foreign tourists in 2016 is 12 million. The target of domestic tourists is 260 million trips," Tourism Minister Arief Yahya said at the Tourism Ministry's Year-End Press Conference on December 20, 2015.

According to the Central Statistics Agency (BPS) report, foreign tourist arrivals to Indonesia in May 2016 had reached 915.2 thousand visits as stated directly by the Head of BPS Suryamin at the Press Conference at the BPS Building, Jakarta, Friday (1/7/2016). ) Tourists who came to Indonesia during the fifth month had already reached 915.2 thousand visits, up 1.57 percent compared to last April which reached 901.95 thousand visits. While compared to May last year which recorded 852.38 thousand visits, the realization in May 2016 experienced an increase of 7.37 percent. The purpose of tourism is to increase national income and improve the welfare and prosperity of the people. Currently consumer preferences in enjoying tourist objects have undergone a change which refers to the form of special interest tourism namely ecotourism. Indonesia is very rich in the potential of natural tourism (ecotourism), one of which is natural tourism in the region PKT Bogor Botanical Gardens in the city of Bogor. Bogor Botanical Garden is an ex-situ conservation area that has long been used by the wider community as a tourist attraction and in many countries, KRB has become one of the most popular tourist destinations because it presents a panoramic view of natural landscape architecture. Indonesia has a cultural landscape and a historical landscape with high values and diversity, both related to the socio-economic life of the community and related to state political travel (Umar, Nurisjah, \& Avenzora, 2010) . Bogor has a tourist attraction that is a mainstay for the city of Bogor so that foreign tourists visit Bogor, namely the Bogor Botanical Gardens. The tourist object that contains various types of plants and plants with a cool shady atmosphere was established and established as the Bogor Botanical Gardens on May 18, 1817. Until now, the Bogor Botanical Garden which has an area of 87 hectares is still a tourist destination in the city of Bogor which is crowded with tourists overseas. Foreign tourists who come to Jakarta will take the time to come to the Bogor Botanical Gardens because of the relatively close distance between Jakarta and Bogor. Under the auspices of LIPI (UPT Botanical Gardens Development Center-LIPI, 2000) the Bogor Botanical Gardens began to make changes. Some of the roles carried out by the Bogor Botanical Gardens are: 1) exploration of plants in all parts of the world to be cultivated; 2) acclimatization and introduction of plant species of economic value to be cultivated; 3 ) education of the facts of plant life and botany-related sciences such as forestry and agriculture for students, students and the general public; 4) recreational facilities and scientific tourism; and 5) conservation activities (Heywood, 1989). Determination of Kebon Raya Bogor as UPT based on the Decree of the Chairperson of the Indonesian Institute of Sciences No. 25 / Kep / D.5 / 1987. With the status change to UPT. Kebon Raya Bogor is required to try to convert its collection 
more directed by developing certain rare and endangered plants to be returned to their habitat or other places and introduce them to cultivated communities. Another major step is to propose Bogor Botanical Gardens to become UNESCO World Heritage, that's required many changing on the management and vision. Based on the description of the above background, the researcher is conducted research under the title Analysis of Tangible strategy for Kebun Raya Bogor (KRB) in Service Improvement and Management as an Observation and Heritage Area.

\section{Problem Identification}

Based on the description of the background above, the formulation of the problem can be formulated as follows:

1. What is the vision, mission of the Bogor Botanical Gardens (KRB) as a Conservation and Heritage Area?

2. How do internal and external factors encourage the Bogor Botanical Gardens (KRB) as Conservation and Heritage Areas?

3. What are the efforts of the Bogor Botanical Gardens (KRB) in improving service and management as a Conservation and Heritage area?

\section{Research Objectives}

1. Studying KRB's Vision and Mission in relation to the dynamics of demands from external parties;

2. Observe the interaction between external and internal business environment factors that drive changes in the KRB;

3. Observe the forms of tangible strategy underway at KRB

\section{Types of Research}

This research uses a qualitative approaches. This study consists of primary and secondary data collection based on the type of participation that is followed by the analysis of data. The collection of data through a qualitative approach is to conduct in-depth interviews with key informants. Data collection begins with qualitative interviews with key informants

A. Research Focus

The focus of research is important of management change for the process of World Heritage.

B. Method of Data Collection

This method is done by examining the various documents to complete the data: the general conditions of the study area, the role of local communities, NGOs work program associated with BBGs, and programs of local government that related with the management of BBGs.

C. Data Analysis

This research uses qualitative data, the statistics used to analyze the data in a way to describe or depict the data that has been collected. The data is described in terms of the themes.

\section{Literature Review}

1. Bogor Botanical Garden

Bogor Botanical Garden is located in the middle of Bogor City, in Paledang Village, Bogor Tengah District. This Botanical Garden was established on May 18, 1817 with the name's Land Plantentuin te Buitenzorg. According to Sarilestari (2009), the Bogor Botanical Garden was originally part of a samida (artificial forest / artificial garden) that had existed since the reign of Sri Paduga Maharaja (Prabu Siliwangi, 1474-1513) from the Pajajaran kingdom. The function of the KRB is to preserve the environment as a place for rare wood seeds. At first the garden will only be used as a trial garden for plantation crops which will be introduced to the Dutch East Indies (currently Indonesia). But in its development it was also used as a forum for research scientists since 1880-1905. This Bogor Botanical Garden is the forerunner of research institutions in Indonesia and internationally. In the beginning, the Bogor Botanical Garden was only a part of the courtyard of the Bogor Palace, where at that time, the Bogor Palace was the first building built in the colonial period, as the resting place of the Governor of the Dutch General. Gradually, the Bogor Botanical Gardens underwent a gradual change in area, from just a section of the palace courtyard to a very important area of research The development of the Botanical Gardens began from the beginning of its formation, namely in 1817 until 1927. Initially, namely in 1817, the Bogor Botanical Gardens were only limited to the Ciliwung River, At present the Bogor Botanical Garden is a large research garden covering an area of 87 hectares. However, due to the development of the city of Bogor from time to time, currently KRB has an area of 84 hectares, because some assets are released from the management of KRB. KRB and Bogor Palace are one landscape unit even though the management is different. KRB by LIPI and Bogor Palace by State Administration.

\section{Management Strategy}

a. Definition of Management Strategy

1. According to (Wheelen \& David Hunger, 2012): Strategic management is a series of managerial decisions 
and actions that determine a company's long-term performance.

2. According to Fred R David (David, 2011) Strategic management is the art and knowledge to formulate, implement, and evaluate cross-functional decisions that make an organization able to achieve its objectives.

3. According to (Hariadi, Sunarto, \& Sudarmaningtyas, 2016) 3)Strategic management is a process that is systematically designed by management to formulate strategies, execute strategies and evaluate strategies in order to provide the best values for all customers to realize the organization's vision.

b. Management Process Theory Strategy:

1.According to Wheelen and Hunger(Wheelen \& David Hunger, 2012) The strategic management process includes 4 basic elements, namely:1. Environmental observation, 2. Strategy formulation, 3. Implementation of the strategy, and 4. Evaluation and control.

2. According to Pontas M. P. (2011)1. Strategy Planning, a. Formulation of objectives b. Formulation of company values, beliefs, philosophy and policies, c. Assessment or measurement of strengths, weaknesses, opportunities, and threats related to the company.

Company strategy formulation, 2. Implementation and control of tactics, a. Strategy, b. Strategy assessment and control. 3. Tangible strategy.

Definition of Change and Change Management.

Change is a transformation from the present state to the expected condition in the future, a better condition. Changes in signs in life that always take place constantly. If there is no change, there will be stagnation and life cannot develop. Tangible strategy is a systematic process in applying the knowledge, tools and resources needed to influence changes in people who will be affected by these changes. (Potts and LaMarsh are adopted by Wibowo). According to Prof. Dr. J. Winardi (Winardi, 2006), tangible strategy is an effort taken by managers to manage change effectively, where understanding about issues of motivation, leadership, group, conflict, and communication is needed. Based on the opinions above can be synthesized Tangible strategy is a systematic process, effectively implementing facilities and resources where motivation, leadership, group, conflict and communication are needed with indicators: (1) Continuous implementation; (2) the desire to change.

b. Various types of change management.

There are 2 kinds of changes, namely: 1. changes naturally (natural change) and 2. A planned change he difference between natural and planned change itself can be seen from the process, for natural changes the process is usually not directed and for planned changes is usually directed. Besides that we can also see what changes have occurred in us through progress and growth. Usually when the changes we make are planned, we must have a vision; both ideals, hopes, views, goals and future c. Benefits, Types, Objectives and Components in Change Management

1. Benefits of Change Changes have benefits for the survival of an organization, without changes, it can be ascertained that the age of the organization will not last long.Change aims for the organization not to become static but to stay dynamic in the face of the times, technological advances and in the field of health services are increasing awareness of quality services

2. Type of Change: Change consists of 3 different types, where each type requires a different tangible strategy. The three types of changes are:

a. Routine Change, which has been planned and built through an organizational process;

b. improved change, which include the benefits or values achieved by the organization;

c. Innovative changes, which cover how the organization provides its services.

Basically none of the approaches are suitable for Change Management. The methods used for communication, leadership, and coordination of activities must be adjusted in finding the needs of each change situation.

3. Purpose of Change 1. Maintaining the survival of the organization both short and long term adapting to changes that occur in the internal environment which includes changes in corporate strategy, labor, technology and equipment used and attitudes of employees, as well as the external environment of the organization such as changes in the consumer market, technology, government regulations and laws as well as the global economy.3. Improve effectiveness within the organization in order to be able to compete in the modern economy market which includes improving the effectiveness of the work team and improving the structure and system of the organization in this regard related to strategy implementation

A number of models or concepts regarding change are provided to clarify an understanding of the management of changes that need to be carried out by the organization:

1. Force Field Theory: This theory suggests that change occurs because of the emergence of pressures on organizations, individuals or groups, where the driving forces are faced with resistances to change so that a change occurs it must strengthen driving forces and weaken resistances.

2. Motivation Theory: in this theory changes will occur if there are certain conditions that are beneficial. But by having the motivation to change, what needs to be done is to focus on the future by discarding pessimistic 
attitudes, creating compliance, and reducing dissatisfaction.

3. Theory of Alpha, Beta, and Gamma: In this theory the change in Alpha is a change in the level of trust that occurs, Beta changes are changes that occur in assessing trust, while changes in Gamma are changes that occur because the group sees other factors that are more important.

4. Contingency Theory: in this theory what is observed is the level of success of decision making determined by the style adopted in managing change and a number of possibilities.

5. Theory of Cooperation: the theory of cooperation learns that change cannot work without the cooperation of all parties.

6. Theory of Overcoming Resistance in Change: this theory discusses the techniques used in overcoming resistance such as communication, participation, facilitation, negotiation, manipulation to forced techniques.

7. Accounting-turnaround model: this theory sees that to be saved by a corporation must have a number of conditions such as stakeholder support, there are core businesses that are able to bring cash flow, a solid management team, and funding sources especially for the long term. Usually companies that do turnaround are companies that experience a decrease due to continuous losses or mismanagement.

Driving factors for change Among the experts there are those who cite the drivers of this change as the need for companies (Hussey) (HUSSEY, LANGHAM, Kreitner, \& Kinicki, 1998), Kreiner and Kinicki,(Kreitner \& Kinicki, 2007). Meanwhile, Robbins (Robbins, 1989) and Greenberg and Baron (Greenberg, Baron-Cohen, Stillwell, Kosinski, \& Rentfrow, 2015)mention it as a force for change. The terminology implies that the need for change is more of an internal organization, while the power for change can be derived from internal and external factors.

1. Needs for Change Hussey According to Hussey (HUSSEY et al., 1998) there are six factors that are the drivers of the power of change, as follows. a. Technology changes continue to increase

b. Competition is intensifying and becoming more globalized c. Customers are increasingly demanding $\mathrm{d}$. The countries demographic profile changes e. The privatization of community-owned businesses continues $\mathrm{f}$. Shareholders ask for more value

2. Needs to Change Kreitner and Kinicki Meanwhile Kreitner and Kinicki (Kreitner \& Kinicki, 2007) note that the need for change is influenced by two factors, namely external strength and internal strength.

3. Strength of Change in Greenberg and Baron Greenberg and Baron (Greenberg et al., 2015)argue that there are several factors which are the forces behind the need for change. They separate between planned changes and unplanned changes.

4. The Need for Change in Robbins (Robbins, 1989) reveals the existence of 6 factors which are the strengths for change, as follows. a. Nature of labor b. Technology c. Economic shock d. Competition e. Social trend $f$. World politics

B. Previous Research

1. Research conducted by Budi Sulston(Hartono, Sulistyo, Praftiwi, \& Hasmoro, 2014) with the title Management Analysis of Corporate Strategy case study of PT. Avira Finance. It was concluded that the strategy carried out was the right thing, it could be seen from the achievements, especially in the field of marketing and finance, which had increased. In anticipating changes, especially external companies make changes in the strategy in improving their business.

2. Research conducted by Ezra Randalinggi (Parrangan, 2015) Analysis of Company Strategies in Foreign Market Expansion of case studies of PT. Semen Indonesia (Persero) Tbk. The strategy is to acquire a cement company in Vietnam's Thang Long Cement Company. Expansion strategies carried out using existing opportunities, among others, take advantage of the crisis conditions that occur in the State of Vietnam to get the lowest prices and the condition of companies that are in need of funds, while the strength possessed by PT. Semen Indonesia is with its financial strength strategy.

3. The research conducted by Engkos Achmad Kuncoro (Kuncoro, 2016) with the title Analysis of Formulation Strategy case study of PT. Samudra Nusantara Logistindo (NSL). The strategy carried out is by conducting market penetration, product development and market development.I.

4.the research conducted by Agustinus Haryadi (DP, Parashakti, \& Mercubuana, 2016) mentidoend about strategic agreesitvy on the company states that the important to have change into management strategy.

\section{Discussion}

A. Tasks, Functions and Organizational Structure

The tasks, functions and organizational structure of the PKP-LIPI Botanical Garden are based on the Head of the Indonesian Institute of Sciences Regulation Number 1 of 2014, dated 9 May 2014, concerning the Organizations and Work Procedures of the Indonesian Science Institute as follows:

Task:

Carry out research in the field of conservation of botanical garden plants and the development of conservation areas of ex situ plants Function: 
Preparation of technical policies, plans and research programs in the field of conservation of botanical gardens; Research in the field of conservation of botanical garden plants;

Monitoring, evaluating and reporting on the implementation of research in the field of conservation of botanical gardens; and

Implementation of administrative affairs. The Botanical Gardens as an area have 5 (five) main functions, namely:

1. The function of conservation is to preserve the diversity of plant species ex situ to be used as a collection of references with high scientific value, developed potential for sustainable use, and become an important backing for efforts to restore plant species threatened with extinction and restoration of degraded lands.

2. The function of research is to carry out and facilitate various research and development activities in the fields of conservation, domestication and reintroduction of plants.

3. The function of education is to provide clear information and provide convenience for visitors to increase knowledge in the fields of botany, conservation, environment and utilization of plants; and to stimulate the growth and development of awareness, concern, responsibility and community commitment to plant preservation.

4. The recreational function is to create natural tourism that has the content of science, while also being comfortable, safe, refreshing and inspiring to support a better social life.

5. The function of environmental services is to provide an ecological impact for improving environmental quality which includes water management, biodiversity, carbon absorption and the beauty of landscapes.

Organizational structure

PKT Botanical Gardens-LIPI organizational structure based on the Regulation of the Head of the Indonesian Institute of Sciences number 1 Year 2014 dated 9 May 2014 concerning LIPI's Organization and work procedures, as follows:

PKT Botanical Gardens-LIPI is led by a Head of Center (Echelon II) in charge of 3 (three) Echelon III, namely:

a. Field of Plant Conservation ex situ,

b. Field of Plant Conservation Area Development ex situ; and c. Administration Section.

c. The Head of Ex situ Plant Conservation Division is headed by a Head of Division in charge of 2 (two) Subfields (Echelon IV), namely :a. Subdivision of Registration and Nurseries; and

d. [b. Subdivision of Plant Collection Maintenance

The Head of Ex Situ Conservation Area Development Division is chaired by a Head of Division in charge

e. of 2 (two) Subfields (Echelon IV), namely:

a. Sub Section of Ex Situ Plant Conservation Area Development Planning; and

b. b. Subdivision of Monitoring and Evaluation of Ex Situ Plant Conservation Area Development

c. The Head of the Administration Section is led by a Section Head who oversees 4 (four) Subdivisions (Echelon IV), namely:

a. Financial Subdivision;

b. Staffing Subdivision;

c. Cooperation and Information Sub-Section; and

d. General Subdivision.

5. Guidance lines for UPT Plant Conservation Center Cibodas Botanical Gardens, UPT Plant Conservation Center Purwodadi Botanical Gardens and UPT Plant Conservation Center Botanical Gardens "Eka Karya" Bali;

Researcher Functional Groups that are non-structural. n purpose for:

1. Improving the quality and quantity of plant collections as a collection of references of scientific value.

2. Facilitating the development of ex situ conservation of plant areas in the form of regional botanical gardens.

3. Strengthening core competencies in the fields of research on conservation, domestication and reintroduction through conservation actions and preparation of research results to be used in the formulation of policies related to the field of conservation, development of plants that have the potential for sustainable use, and recovery of threatened species extinction and / or degraded area.

4. Increasing public awareness through environmental education activities and providing scientific information about plantations and plant conservation.

5. Increasing user satisfaction.

6. Strengthening the role and existence of the PKP-LIPI Botanical Garden at national and international levels.

7. Realizing good organizational governance.

8. Increase the carrying capacity of facilities and infrastructure, especially in improving the quality of public services and research.

Specifically, the targets to be achieved by the PKT Botanical Gardens-LIPI, include:

1. Maintenance of gardens and management of collections of plants in accordance with the rules of plantation. 
2. Increasing the number of collections (especially new collections, new and new types of recordings); and the increasing quality of collections (the data is complete and accurate, as well as information related to its biological character).

3. Increasing and development of plant conservation areas ex situ in the form of regional botanical gardens.

4. Implementation of conservation actions both types and regions.

5. Availability of materials for policy formulation in the field of conservation.

6. Selection of plant species has the potential for further development.

7. The recovery of plant species threatened with extinction and degraded areas.

8. Availability of environmental education packages and scientific information packages in the fields of plantation and conservation, to increase public awareness.

9. Fulfill the expectations and needs of users so that satisfaction increases.

10. The stronger the role and the existence of the PKP-LIPI Botanical Garden at national and international levels.

11. The realization of good organizational governance.

12. Fulfillment of supporting capacity of facilities and infrastructure optimally, especially in improving the quality of public services and research.

c. Policy

Some policies are formulated to support the success of achieving these goals and objectives, especially by:

1. Arrange the priority of activities by adhering to the principle of prioritizing collections in every planning and implementation of activities.

2. Focusing on adding and multiplying collections of rare, endemic, economic value and / or valuable plant species.

3. Facilitate access to collection database.

4. Support the development of proportional new botanical gardens.

5. Increasing the capacity and welfare of employees by opening as many opportunities as possible for employees to improve education and expertise.

6. Increasing national and international cooperation.

7. Complete facilities and infrastructure.

8. Improve the quality of public services.

d. Strategy

The strategies that will be applied to achieve the goals and objectives are:

1. Strengthening the legal-formal authority of the institution through legal products in the form of the Republic of Indonesia's Presidential Regulation on Botanical Gardens;

2. Strengthening the core competencies of institutions at national and international levels;

3. Focus on 4 (four) main areas, namely: institutions, management of plant collections, research (which is more specifically focused on 3 main areas, namely Conservation, Domestication and Plant Reintroduction), and implementation of National Priorities (9th National Priority);

4. Prioritizing an integral approach in planning and implementing activities in the 4 main areas as mentioned above, by placing corporate interests as a reference;

5. Strengthening relationships and networking with related stakeholders.

The idea of changing status and organization and emphasizing activities as a center for plant activation adds to the 'tasks and functions carried out by the Bogor Botanical Gardens (KRB). This institution is required to try to conserve its collection more directed by developing certain rare and endangered plants to be returned to their habitat or to other places and introduce them to the community for cultivation. Facing this change KRB has taken steps to prepare itself for new tasks and functions.

Things to do to deal with changes include:

a. Conduct work evaluations to improve management systems,

b. Make strategic planning, organize research groups, and add facilities and infrastructure, as well

c. Improving human resources.

It is expected that there will be improvements at all levels dang, KRB will be ready and able to carry out new tasks and functions to the fullest. This is in line with one of the objectives of the Strategic Policy for the Development of National Science and Technology issued by the KMNRT which emphasizes repositioning of institutions. As a result, an institutional strategic plan is needed. Facing the new focus of assignments and the demands of the wider community and the scientific development of international plantations, the development of the KRB must be based on planning that leads, to make KRB a conservation center, provider of research, education and scientific tourism. The results of the analysis of the vision and mission summarized from several respondents' opinions and have been refined show that KRB's vision should be "to become a leading institution as an international standard reference in the field of plantations and as a vehicle for ex-situ conservation, especially Indonesian tropical plants". Likewise the KRB mission should be "managing, researching, promoting, utilizing, and developing the potential of plants for concentration, research, education, recreation and meeting the needs of the general public and increasing public appreciation." towards botanical gardens, plants and the environment in an effort to sustainably use the welfare of 
the community on an ongoing and independent basis. "In the Republic of Indonesia PERPRES No. 93 of 2011 [Article 1, number 1] Botanical Gardens are defined as ex situ plant conservation areas that have documented collections of plants based on patterns of taxonomic classification, bioregion, thematic, or a combination of these patterns for purposes conservation, research, education, tourism and environmental services activities. The Plant Conservation Center (PKT) - the LIPI Botanical Garden as an ex situ conservation institution of plants is undoubtedly one of the main pillars for efforts to save the types of plants from extinction. In general, the core competencies of the IPP-LIPI Bogor PKT relating to plant conservation include preparing materials for formulating policies on ex situ tropical plants conservation, developing ex situ conservation areas and rare plant conservation models, carrying out plant conservation and utilization research, reintroduction and recovery (recovery). ) types of tropical plants, as well as the development of environmental education. Ex situ conservation of plant programs includes preservation, research, and development of its use. Plant preservation is done by collecting endangered plants to be conserved in the Botanical Gardens. Collection of plants in the Botanical Gardens is maintained as well as possible and strived to be cultivated for reintroduction to its natural habitat. Besides that, it is also disseminated to the public. The Botanical Garden is not only a place for collection of plants, but also as a venue for environmental education. Therefore, in the Botanical Gardens there are various facilities that can support environmental education activities, such as interpretation boards, flora tourism services, tour guides, student and student guidance. The pattern of this activity will continue to be developed in accordance with the progress of science. Attention to students visiting the Botanical Gardens is given specifically, given that understanding love for plants and the environment will be more effective if done from an early age, which in turn will play a role and maintain the preservation of plants. The Botanic Garden has long been used by the wider community as a tourist attraction, and in many countries, the Botanical Gardens are one of the most popular tourist destinations because they offer a panoramic view of natural architecture. This role is becoming more popular because visitors can enjoy the beauty of the botanical garden as well as add insight and knowledge about plants. All the roles of the Botanical Gardens position it as a multifunctional institution and require complex management C. Internal and External Factors Based on the results of identification of the internal and external environment of the KRB, the factors that can be used as a source of strength for KRB are:

a) changes in the status of the KRB to the Bogor Botanical Gardens Plant Conservation Center with the position of the echelon II institution,

b) the main tasks and functions carried out by KRB are extended to become conservation, research, educational and recreational support institutions "

c) the organizational structure of the KRB as a Plant Conservation Center is leaner and more specialized,

d) the management of activities handled by the KRB is good enough

e) KRB output in the form of scientific information, service, goods or other forms.

The results of the internal environment analysis also show the weaknesses of the KRB, namely:

a. KRB's organizational structure is slim but not perfect because it is too concise,

b. the overall program planning for the implementation of the activities has not been good enough,

c. comparison he size of human resources is not balanced,

d) Equipment, facilities and infrastructure are not enough or still not functioning properly, and

e) fund planning and allocation of cash funds depending on the state budget.

The results of the analysis of the external environment show several factors that are opportunities for the KRB, namely:

KRB policy on L1PI, Jakstra IPTEKNAS I, I 2000-2004, government policies as well as the Regional Autonomy Law,

cooperate with national and international bodies to anticipate competitors who are easy to get "fund raising",

the popularity of KRB in the eyes of the national and international community is very high so that the competitiveness and attractiveness offered by KRB is quite strong,

Improve the function of the KRB as a public tourism object and not specialize in scientific tourism, and Mobilizing partnerships with NGOs engaged in conservation and environmental education.

Then external factors that can threaten the sustainability of KRB activities as a Plant Conservation Center are:

The existence of free trade between the WTO, AFTA and APEC,

$\mathrm{KRB}$ is not ready to differentiate the products or services it offers,

○ many competitors who are easy to get "fund raising",

- d) still lack of electronic information facilities (telecommunications) and the development of sophisticated information technology (home pages, web sites), and

- There is no ex-situ conservation technology (seed banks, tissue culture) so that ex situ conservation technology must still be imported.

D. Tangible strategy

The aim of the upcoming Bogor Botanical Gardens is to make changes to the status of his new organization as a Plant Conservation Center and the objectives of KRB are: 
a) inventory and collection of plants in various regions on the island of Sumatra and Java,

b) b) research, development and utilization of several potential groups of plants, rare plants, seed conservation and landscape architecture,

c) excavation, disclosure and socialization of potential collection plants,

d) multiplication of some rare plant species,

e) construction and development of ex situ conservation areas in Jambi and Kediri,

f) f) institutional restructuring,

f) improve the quality of human resources, and

g) Enhance cooperation with government, private sector, education at national and international levels.

In the SWOT matrix approach a basic alternative strategy is produced to be implemented in the planning strategy that consists of

a) expansion strategy (SO strategy) includes strengthening the system nationally; improve the optimal function of the KRB as a means of research, education, tourism and the center of the commercialization of Iitbang results; improve tourism services;

b) Diversification strategy (ST strategy) includes improving communicative information management; enhance the ability to carry out innovative innovations for commercial purposes;

c) consolidation strategies (WO strategy) include building partnerships with national and international bodies in the field of ex situ conservation; build conservation technology, increase use of genetic resources \& development of ex situ conservation areas and

d) Restructuring strategy (WT strategy) includes the flexibility of the organization's management of the changes that occur and forming quality human resources in their respective fields.

\begin{tabular}{|c|c|c|}
\hline $\begin{array}{l}\text { Internal factor } 1 \\
\text { External }\end{array}$ & Strength (S) & Weakness (W) \\
\hline Opportunity (O) & $\begin{array}{l}\text { strengthen the system nationally; } \\
\text { improve the optimal function of } \\
\text { the KRB as a means of research, } \\
\text { education, tourism and the center } \\
\text { of the commercialization of } \\
\text { Iitbang results; improve tourism } \\
\text { services }\end{array}$ & $\begin{array}{l}\text { build partnerships with national } \\
\text { and international bodies in the } \\
\text { field of ex situ conservation; } \\
\text { build conservation technology, } \\
\text { increase use of genetic resources } \\
\& \text { development of ex situ } \\
\text { conservation areas }\end{array}$ \\
\hline Treat (T) & $\begin{array}{l}\text { improve communicative } \\
\text { information management; } \\
\text { improve the ability to carry out } \\
\text { innovative innovations for } \\
\text { commercial purposes }\end{array}$ & $\begin{array}{l}\text { includes the flexibility of the } \\
\text { organization's management of } \\
\text { changes that occur and forming } \\
\text { quality human resources } \\
\text { according to their respective } \\
\text { fields }\end{array}$ \\
\hline
\end{tabular}

Figure 1.1. SWOT

\section{Conclusions}

The vision and mission of the Bogor Botanical Gardens are still in accordance with the current organizational context in the form of a balance between the conditions of the external environment (expectations and demands of external stakeholders) and internal (organizational capabilities). The dynamics that occur from these two factors have been managed through Tangible strategy by providing management focus and performance that are in accordance with the stipulated Strategic Plan period but still in the Mission and Vision. The efforts that have been made include increasing the intensity of research and cultivation of tropical plants from natural forests as a fulfillment of the research function and at the same time building conservation infrastructure that surrounds the KRB as a form of fulfilling. To be the World Heritage.

\section{Reference}

David, F. R. (2011). Strategic Management Concepts and Cases- 13th ed. Prentice hall. https://doi.org/10.1688/ZfP-2014-03-Rowold

DP, D. A. H., Parashakti, R. D., \& Mercubuana, M. N. (2016). Strategic Aggressitivity And Response Of Companies In Integrating Environmental, Health And Safety Management And Its Effects To Financial Performance. The International Journal of Organizational Innovation.

Greenberg, D. M., Baron-Cohen, S., Stillwell, D. J., Kosinski, M., \& Rentfrow, P. J. (2015). Musical preferences are linked to cognitive styles. PLoS ONE. https://doi.org/10.1371/journal.pone.0131151

Hariadi, B., Sunarto, M. J. D., \& Sudarmaningtyas, P. (2016). Development of Web-Based Learning Application for Generation Z. International Journal of Evaluation and Research in Education (IJERE). 
https://doi.org/10.11591/ijere.v5i1.4523

Hartono, B., Sulistyo, S. R., Praftiwi, P. P., \& Hasmoro, D. (2014). Project risk: Theoretical concepts and stakeholders' perspectives. International Journal of Project Management. https://doi.org/10.1016/j.ijproman.2013.05.011

Hotimah, O., Wirutomo, P., \& Alikodra, H. S. (2015). Conservation of World Heritage Botanical Garden in an Environmentally Friendly City. Procedia Environmental Sciences, 28(SustaiN 2014), 453-463. https://doi.org/10.1016/j.proenv.2015.07.055

HUSSEY, D. E. E., LANGHAM, M. J., Kreitner, R., \& Kinicki, A. (1998). Management consulting. In Corporate Planning. https://doi.org/10.1002/(sici)1099-1697(199808)7:5<249::aid-jsc373>3.3.co;2-6

Kreitner, R., \& Kinicki, A. (2007). Organizational Behavior: An Interdisciplinary Field. In Organizational Behavior.

Kuncoro, E. A. (2016). Analisis Perumusan Strategi Bisnis pada PT Samudera Nusantara Logistindo. Binus Business Review. https://doi.org/10.21512/bbr.v1i1.1065

Parrangan, E. R. (2015). Analisis Strategi Perusahaan Dalam Ekspansi Pasar Luar Negeri (Studi Kasus Pada PT. Semen Indonesia ( Persero ) Tbk dalam Akuisisi Thang Long Cement Company di Vietnam). Ekonomi.

Robbins, P. S. (1989). Organizational Behavior: Concepts, Controversies, and Applications. New Jersey: Prentice Hall.

Umar, F., Nurisjah, S., \& Avenzora, R. (2010). Identifikasi dan Rencana Pengembangan Kawasan Wisata Budaya Koridor Sungai Kapuas - Kota Pontianak. Jurnal Lanskap Indonesia.

Wheelen, T. L., \& David Hunger, J. (2012). Strategic Management and Business Policy Toward Global Sustainability Thirteenth Edition. Strategic Management and Business Policy Toward Global Sustainability.

Winardi, J. (2006). Teori Organisasi \& Pengorganisasian. Teori Organisasi \& Pengorganisasian. https://doi.org/10.1302/0301-620X.93B1.24767 